Original Research

\title{
Rheological Study on Seawater Contaminated with Oil Components
}

\author{
Ehab Bani-Hani', Muhammad Tawalbeh ${ }^{2}$, Amani Al-Othman $^{3}$, \\ Mamdouh El Haj Assad ${ }^{2 *}$
}

\author{
${ }^{1}$ School of Engineering, Australian College of Kuwait, Mishref, Kuwait \\ ${ }^{2}$ SREE Department, University of Sharjah, Sharjah, UAE \\ ${ }^{3}$ American University of Sharjah, Sharjah, UAE
}

Received: 19 April 2018

Accepted: 10 June 2018

\begin{abstract}
The protection of marine life and prevention of pollution caused by accidental oil spills in seawater have become a critical issue. Thus, quick actions should be executed. One of these actions is the cleanup process, which requires pumping, skimming, and storing the contaminated seawater. This operation requires deep knowledge of the physical and chemical proprieties of pollutant fluid that would help in calculating the power requirements for the cleanup process. This study focuses on the properties of two pollutants: diesel and spent engine oil. Instead of taking on-site samples for analysis, a data bank for these properties would offer an efficient tool to characterize the fluids. The aim of this work was to present a rheological and physiochemical study for the seawater upon the addition of diesel and spent oil pollutants at different concentrations. It was also aimed at investigating the effects of pollutant concentration, mixing time, and temperature on seawater viscosity and density with time. The results of this work will provide a wide range of physical data for a mixture of seawater and crude oil components measured at different temperatures using hydrometer and coaxial cylindrical viscometer standard tests.

The experimental results also showed that there is a significant change in seawater viscosity when contaminated with spent engine oil and diesel oil. The viscosity increased as the concentration of spent engine oil and diesel oil increased within seawater. For example, when the diesel oil concentration increased from $10 \mathrm{vol} \%$ to $50 \mathrm{vol} \%$ rat $25^{\circ} \mathrm{C}$, the viscosity increased from $0.0012 \mathrm{~Pa}$.s to 0.0031 Pa.s.

At the same temperature, the viscosity increased from 0.00173 Pa.s to 0.0036 Pa.s when the spent engine oil concentration increased from $10 \mathrm{vol} \%$ to $50 \mathrm{vol} \%$, respectively. The same trend was observed when the temperature decreased.

The effect of time on the density of seawater contaminated with diesel oil appeared to be insignificant at constant concentration and temperature where the density is almost constant for the 140 minutes
\end{abstract}

*e-mail: massad@sharjah.ac.ae 
of testing time. However, as the concentration of diesel oil increased at constant temperature, the density decreased. The same behavior was noticed when studying the effect of temperature where the density of contaminated seawater decreased as the temperature increased at a constant concentration.

Keywords: oil spill, rheology, viscosity, seawater, density, viscometer

\section{Introduction}

Marine pollution has severely affected marine environments through disruption and even damage [1]. In particular, spills of crude oil and petroleum products resulting from oil exploration or transportation across open water are among the major pollutants [2,3]. Spills occur mostly by accident during drilling or exploration activities and the spilled oil extent is proportional to the depth of exploration [4]. On the other hand, accidents during transportation across open water is another source for large oil spills [5, 6]. For example, the British Petroleum oil spill in the Gulf of Mexico on April 20, 2010, was responsible for releasing 680,000 tons of crude oil that led to the pollution of $9900 \mathrm{~km}^{2}$ of surface water $[7,8]$.

The transportation of oil spills through water appears to be a very complicated process. It is controlled by several factors, including the dispersion, possible dissolution, sedimentation, and biodegradation of the oil components, and emulsification [9].

Emulsification, in particular, is one of the processes that complicates the cleanup process of oil spills [10] and has significant effects on the choice of oil spill recovery. Hence, a clear understanding of the oil spill fate and transportation process is a key element for the development and design of an effective remediation technique.

One of the major concerns with oil spills is drainage of the hydrocarbons into the soil, subsoil, and the substratum, which eventually leads to the contamination of groundwater [11]. In countries that rely on seawater desalination to afford drinking and irrigation water, such as Arabian Gulf countries, oil spills may overpass the treatment procedures and eventually reach drinking water.

Crude oil consists mainly of paraffins, naphthenes, and aromatic hydrocarbons. It also contains oxygen, nitrogen, and sulfur compounds, as well as heavy metals such as nickel, cadmium, lead, and vanadium organometallic complexes. Hence, crude oil is a toxic material that can spread rapidly and harm human health and seriously impact the environment [12]. The major environmental effect will be on marine habitats [13], particularly the growth and reproduction of coral reefs - which is catastrophic for habitats and food chains of numerous marine species [14, 15]. And the oil-dispersant combination is more toxic for coral, in some cases, than the oil alone.

Annually, 1.5 to 10 million tons of crude oil are released to water bodies [16]. This amount of oil spills has a considerable effect on the environment, especially when huge amounts are suddenly released to restricted water bodies. The concentration of pollutants usually determines the clean up as well as safe disposal methods. The former includes the addition of solidifiers, dispersants, shoreline pretreatment agents, and elasticity modifiers [17], while the latter include landfill and incineration [18-20].

The physicochemical properties of oil and its derivative products are expected to change after mixing with saline water [21]. Oil density, viscosity, surface tension, and optical properties, for instance, change significantly due to mixing with saline water [22]. Viscosity is a critical property of fluids and very important in the field of fluid mechanics and its applications. For instance, the density could increase to $1.03 \mathrm{~g} / \mathrm{mL}$ compared to the original oil density ranging between 0.95 and $0.80 \mathrm{~g} / \mathrm{mL}$, while oil viscosity may increase by three orders of magnitude [23]. These changes have a significant influence on the behavior of crude oil spills in saline water. Hence, the objective of this work is to investigate the effect of diesel and spent engine oil on seawater physiochemical properties. The effects of mixing time and temperature will be also studied. The knowledge of these properties will help in the exact calculation for the power requirements in the cleanup process.

\section{Material and Methods}

Samples of seawater were collected from the Arabian gulf of Kuwait with total dissolved solids in the range of $45000 \mathrm{mg} / \mathrm{L}$. The detailed Arabian gulf of Kuwait seawater ionic composition is shown in Table 1 [24]. Seawater samples with different concentrations of diesel and used engine oil were prepared. Diesel and engine oil were selected in this work as they represent two of the most common pollutants that are frequently released to the open water. Commercial diesel was purchased from a local petrol station with characteristics shown in Table 2 [25], while the spent engine oil was collected from a local garage with characteristics also shown in Table 2.

Omsons density petroleum hydrometer (L-50 SP/ M-50 SP ISI, OMSONS - Narindra scientific industries, India) was used to measure the density (relative density) and the two-cylinder rotating viscometer (Thermo Scientific HAAKE Viscotester, Fisher Scientific, and USA) was used to measure the viscosity. Density and viscosity measurements were performed for each sample at different time temperatures. The measurements were also carried out at different temperatures. 
Table 1. Major Elements of Arabian Gulf at Kuwait [24].

\begin{tabular}{|c|c|c|c|c|c|}
\hline Element & Concentration $(\mathrm{mg} / \mathrm{L})$ & Element & Concentration $(\mathrm{mg} / \mathrm{L})$ & Element & Concentration $(\mathrm{mg} / \mathrm{L})$ \\
\hline Oxygen & $8.57 \times 10^{+5}$ & Nitrogen & 0.5 & Manganese & 0.002 \\
\hline Hydrogen & $1.08 \times 10^{+5}$ & Lithium & 0.18 & Vanadium & 0.001 \\
\hline Chlorine & 23000 & Rubidium & 0.12 & Titanium & 0.001 \\
\hline Sodium & 15850 & Phosphorous & 0.07 & Cesium & 0.0005 \\
\hline Magnesium & 1765 & Iodine & 0.06 & Chromium & 0.0003 \\
\hline Sulfur & 3200 & Barium & 0.01 & Silver & 0.0003 \\
\hline Calcium & 500 & Aluminum & 0.01 & Cerium & 0.0004 \\
\hline Potassium & 460 & Iron & 0.01 & Cobalt & 0.000033 \\
\hline Bromine & 80 & Molybdenum & 0.01 & Neon & 0.000014 \\
\hline Carbon & 142 & Zinc & 0.01 & Cadmium & 0.00011 \\
\hline Strontium & 8.1 & Nickel & 0.0054 & Tungsten & 0.0001 \\
\hline Boron & 4.6 & Arsenic & 0.003 & Lead & 0.00005 \\
\hline Silicon & 3 & Copper & 0.003 & Mercury & 0.00003 \\
\hline Fluoride & 1.3 & Tin & 0.003 & Selenium & 0.00002 \\
\hline Argon & 0.6 & Krypton & 0.0025 & & \\
\hline
\end{tabular}

Table 2. Physical and chemical properties of diesel and spent engine oil samples [25].

\begin{tabular}{|c|c|c|c|c|}
\hline \multicolumn{2}{|l|}{ Diesel oil } & \multirow[b]{2}{*}{ Test } & \multicolumn{2}{|l|}{ Spent engine oil } \\
\hline Specification parameter & Result & & Specification parameter & Result \\
\hline Cloud Point, ${ }^{\circ} \mathrm{C}$ & 2 & ASTM D5772/JIS K 2269 & Flash point, ${ }^{\circ} \mathrm{C}$ & 158 \\
\hline $\mathrm{CFPP},{ }^{\circ} \mathrm{C}$ & 1 & IP309/JIS K 2288 & Pour point, ${ }^{\circ} \mathrm{C}$ & -5 \\
\hline Pour Point, ${ }^{\circ} \mathrm{C}$ & 0 & ASTM D 4737/JIS K 2269 & Viscosity index & 89.11 \\
\hline HFRR, $\mu \mathrm{m}$ & 484 & ISO 12156-1/JPI-55-50-98 & Refractive index & 1.4763 \\
\hline Rancimat, $\mathrm{hr}$ & $>30$ & EN 14078 & Specific gravity & 0.9261 \\
\hline $\begin{array}{c}\text { Wax content at } 10^{\circ} \mathrm{C} \text { below } \\
\text { cloud (wt } \%)\end{array}$ & 3.4 & Differential Scanning Calorimetry & Kinematic Viscosity at $40^{\circ} \mathrm{C}$, Cst & \\
\hline Density at $15^{\circ} \mathrm{C}, \mathrm{kg} / \mathrm{m}^{3}$ & 839 & IP 365/JIS K 2249 & Kinematic viscosity at $100^{\circ} \mathrm{C}$, Cst & \\
\hline Viscosity at $40^{\circ} \mathrm{C}, \mathrm{cSt}$ & 4.93 & ASTM D 445/JIS K 2283 & & \\
\hline Sulfur, ppm & 1350 & ASTM D 2622/JIS K 2541-6 & & \\
\hline Cetane index two variables & 58 & ASTM D 4737/ASTM D 976/ JIS K 2280-5 & & \\
\hline Cetane index four variables & 65 & ASTM D 4737/ASTM D 976/JIS K 2280-5 & & \\
\hline Cetane Number & 60 & IP 498 & & \\
\hline Distillation ${ }^{\circ} \mathrm{C}, \mathrm{IBP}$ & 213 & ASTM D 86/JIS K 2254 & & \\
\hline $\mathrm{T}_{10}$ & 268 & & & \\
\hline $\mathrm{T}_{20}$ & 283 & & & \\
\hline $\mathrm{T}_{50}$ & 311 & & & \\
\hline $\mathrm{T}_{90}$ & 351 & & & \\
\hline $\mathrm{T}_{95}$ & 362 & & & \\
\hline FBP & 369 & & & \\
\hline$\%$ FAME & 0 & EN 14078 & & \\
\hline
\end{tabular}




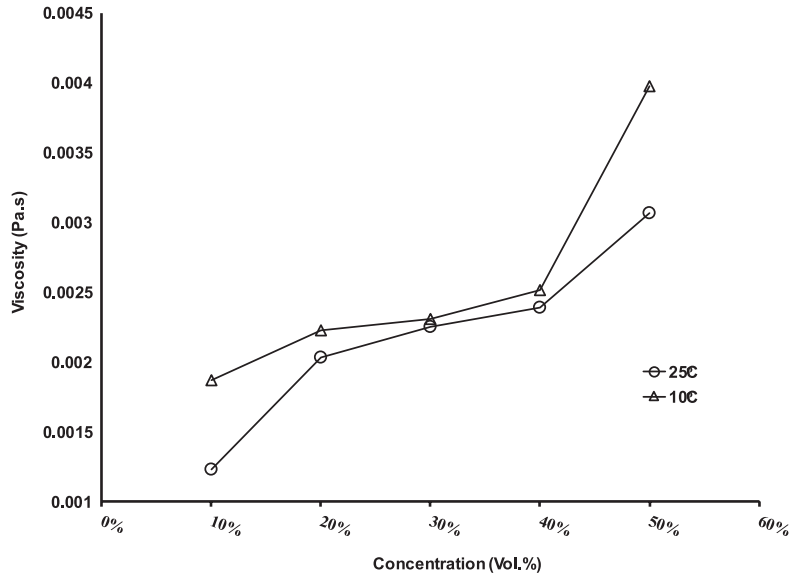

Fig. 1. Viscosity of seawater contaminated with different amounts of diesel oil at $10^{\circ} \mathrm{C}$ and $25^{\circ} \mathrm{C}$.

\section{Results and Discussion}

The effect of diesel on seawater properties at different concentrations is shown in Fig. 1.

In this Figure the viscosity curves are drawn for different diesel concentrations for different temperatures. It can be clearly seen that the viscosity of seawater increases as the concentration of diesel increases, regardless of temperature. This is attributed to the fact that diesel has a higher viscosity than seawater. It is also clearly seen from Fig. 1 that the viscosity at $10^{\circ} \mathrm{C}$ is higher than the viscosity at $25^{\circ} \mathrm{C}$ for the same diesel concentration within the range of diesel concentrations under study. For example, the viscosity at 50 diesel vol\% is $0.003979 \mathrm{~Pa} . \mathrm{s}$ at $10^{\circ} \mathrm{C}$, while it is 0.0030657 Pa.s at $25^{\circ} \mathrm{C}$. It should be mentioned here that the viscosity measurements are done after 24 hours.

The effect of time is also important on the viscosity of the seawater/diesel mixture. Keeping the contamination within seawater for a long time resulted in an increase in viscosity. This increase in viscosity

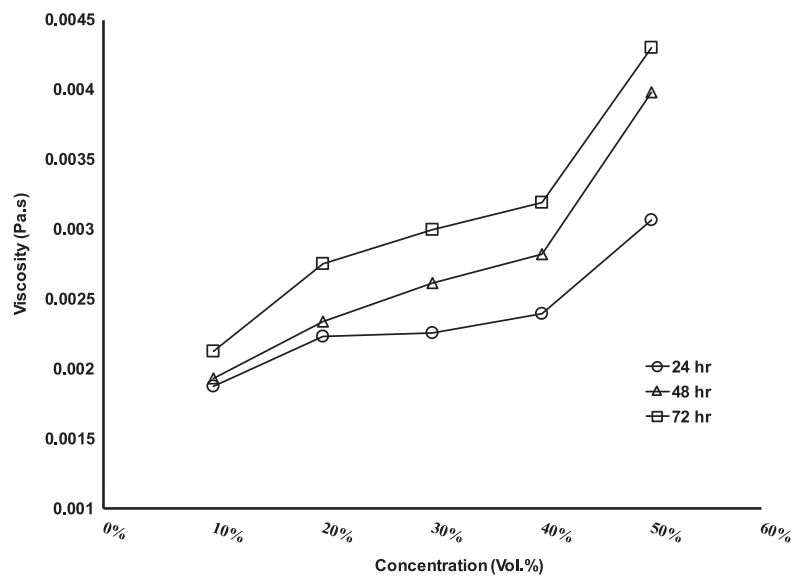

Fig. 2. Viscosity of seawater contaminated with different amount of diesel oil at $25^{\circ} \mathrm{C}$ measured at different time intervals.

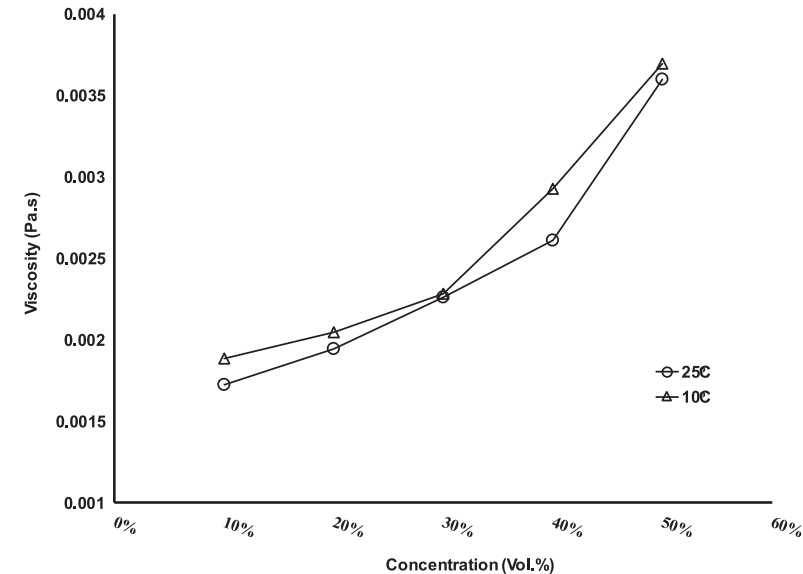

Fig. 3. Viscosity of seawater contaminated with different amounts of spent engine oil at different temperatures measured after 24 hours.

is shown in Fig. 2, where the viscosity was measured for diesel samples with different concentrations that were kept for different time intervals in seawater. It can be seen from Fig. 2 that the viscosity of the seawater/ diesel mixture at $25^{\circ} \mathrm{C}$ increases as the amount of diesel increases and all showed an increase with time as well. Diesel viscosity is higher than that of water. One possible explanation for the increase in time is due to a molecular interaction between water and diesel molecules is happening, leading to an emulsion with more viscosity

Water waves, salinity, and sun accelerate molecular interactions and change other physical properties such as color. For example, at $25^{\circ} \mathrm{C}$ the viscosities of $50 \mathrm{vol}$ diesel \% were 0.003065714 Pa.s, and 0.00429994 Pa.s for 24 hours and 72 hours, respectively. Engine oil is the second major pollutant for marine life, which was also considered in this study. Spent engine oil could escape to seawater from accidents and/or from illegal dumping of the used oil in the open water. Knowledge of the

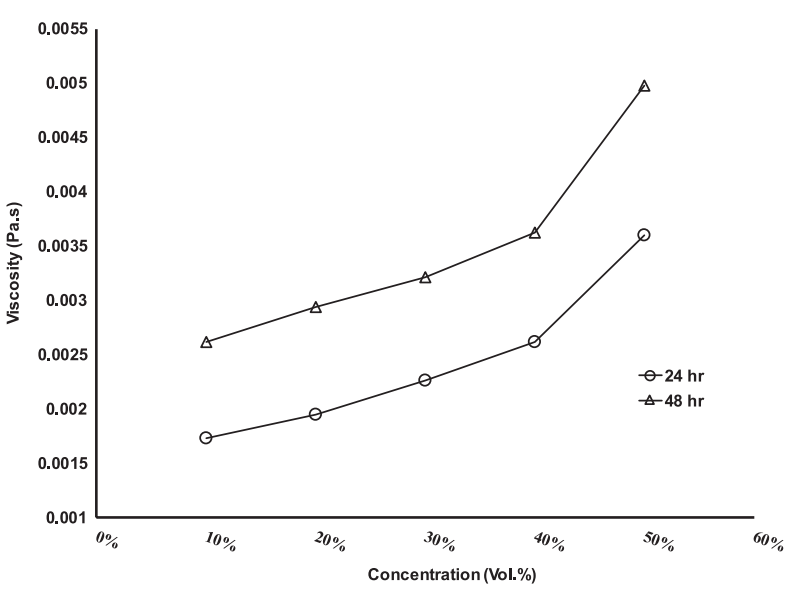

Fig. 4. Viscosity of seawater contaminated with different amounts of spent engine oil at $25^{\circ} \mathrm{C}$ measured at different time intervals. 


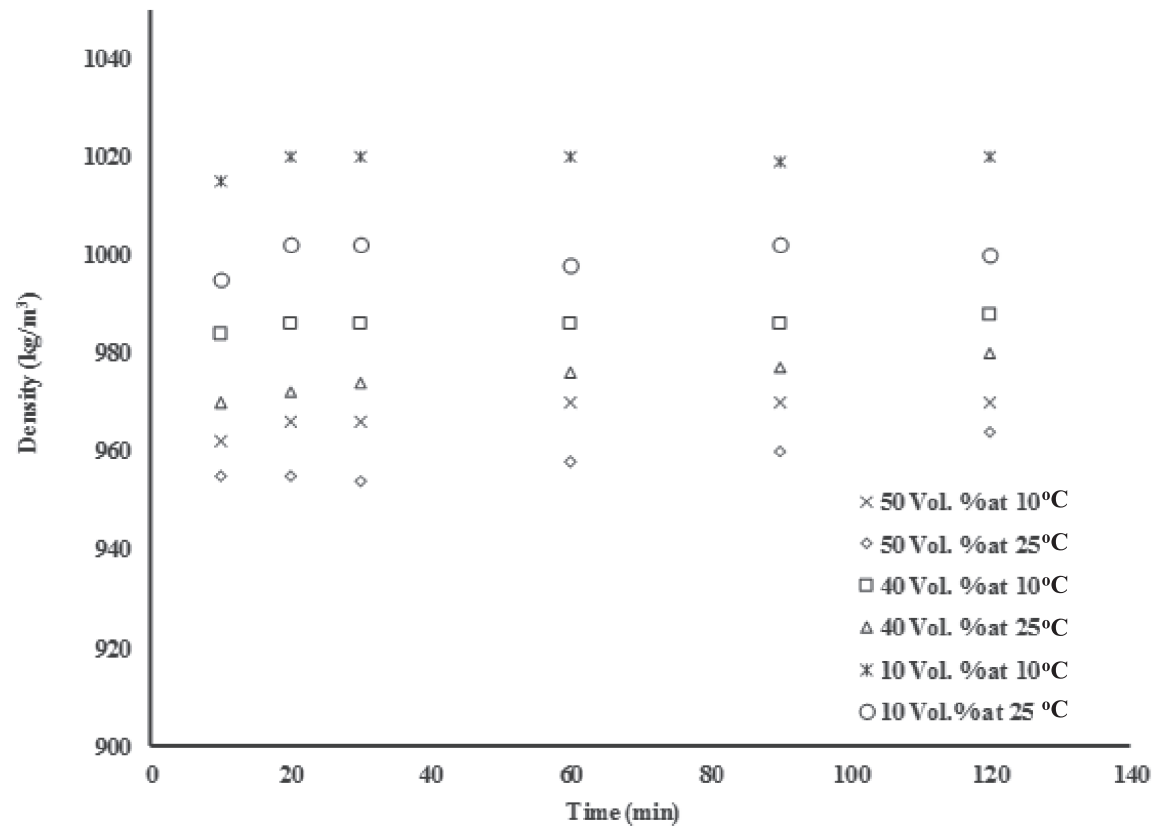

Fig. 5. Variation of seawater/diesel oil mixture density at different concentrations and temperatures.

physical properties of engine oil contaminated seawater along with the time at which the spill or dumping occurred helps in accelerating the cleanup process. A mixture of spent engine oil collected from a local garage was utilized in this study. Engine oil samples were mixed with seawater with different concentrations. These samples were used to evaluate the effect of mixing temperature and time on the density and viscosity of the seawater/engine oil mixture.

Fig. 3 shows the effect of temperature on viscosity of seawater contaminated with spent engine oil. It is evident that there was a significant increase in the seawater viscosity as a result of the presence of spent engine oil at both temperatures 10 and $25^{\circ} \mathrm{C}$. It is also evident that the viscosity decreased with increasing the temperature. In general it can be noticed that this decrease with increasing temperature was less significant at higher engine oil concentrations. It is worth mentioning that these measurements were done after 24 hours from spill time.

The effect of time on seawater viscosity was also investigated. The values of viscosity were taken after

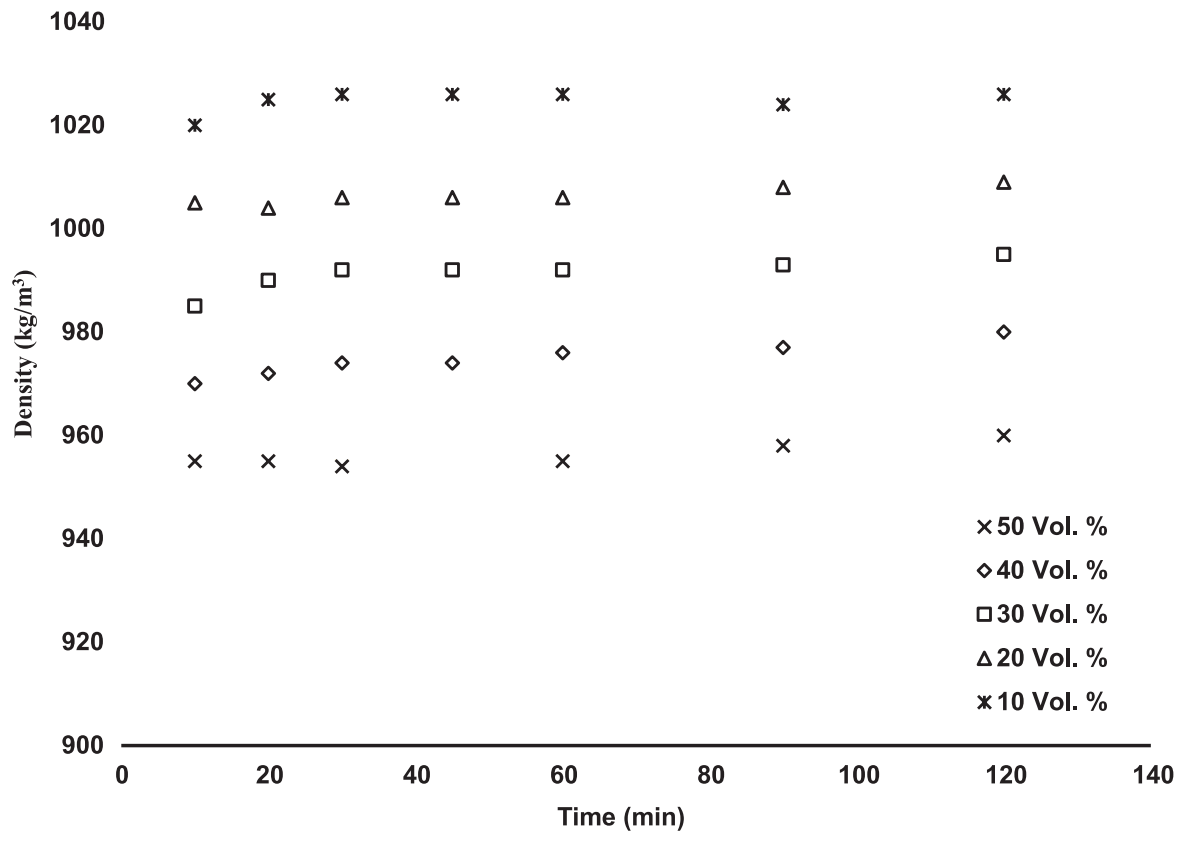

Fig. 6. Change of seawater density contaminated with different concentrations of diesel measured as a function of time at $25^{\circ} \mathrm{C}$. 
24 and 48 hours at $25^{\circ} \mathrm{C}$. The results are shown in Fig. 4, where the viscosity of seawater/engine oil mixtures, with different concentrations, increased with time. It is worth pointing out that it was difficult to measure the viscosity of seawater/engine oil mixtures after 72 hours correctly, as the viscosity became significantly high enough to the point that it could not be measured exactly by the viscometer.

Density was also an important physical property of seawater contaminated with oil and oil components. Thus, the effect of diesel concentration, temperature and time variables were investigated. The results are shown in Fig. 5, which shows the effect of time on the density variation of seawater contaminated with diesel for three different concentrations: 10 vol $\%, 40$ vol $\%$, and $50 \mathrm{vol} \%$ at two different temperatures, 10 and $25^{\circ} \mathrm{C}$. It can be clearly seen that the change of density with time is insignificant. However, there was a notable decrease of density with temperature. This could be due to the evaporation of diesel at higher temperatures, making the density of the seawater/diesel mixture closer to the density of seawater.

The effect of time on density was further investigated for a wide range of diesel oil concentrations. The results are shown in Fig. 6, where it is clearly seen that the density of the seawater/diesel mixture decreased by increasing the concentration of diesel oil. Fig. 6 also shows that for the same diesel oil concentration, the density of seawater/diesel mixture has not significantly changed. It can also be noticed from Fig. 6 that there is a slight increase of density with time, which may be attributed to changes in the properties of seawater as a result of diesel oil presence.

\section{Conclusions}

Seawater undergoes rheology and physical property changes such as viscosity and density because of being contaminated with diesel and engine oil pollutants. Hence, it is important to have a databank of these property changes under different conditions such as temperature and pollutant concentrations to start the cleaning-up process. This study presented the change of density and viscosity with: 1) concentration of pollutants and 2) temperature. The results showed that, in general, there is an increase of viscosity as the amount of pollutant (diesel and engine oil) increased in seawater. The viscosity decreased with temperature. The density of the contaminated seawater decreased as temperature increased at constant pollutant concentration.

The results in this study are very helpful in determining the power required to collect the contaminated seawater by pumping, skimming, and storing operations. Viscosity change is highly affected by temperature variations and concentration. Density shows a little change for the time duration of the study, for example, $40 \mathrm{vol} \%$ of diesel oil at $10^{\circ} \mathrm{C}$ remains constant at $980 \mathrm{~kg} / \mathrm{m}^{3}$ during the duration of the testing. However, we noticed that density decreases as temperature increases at constant concentration, for example, at $40 \mathrm{vol} \%$ the density increases from 960 to $980 \mathrm{~kg} / \mathrm{m}^{3}$ when the temperature decreases from 25 to $10^{\circ} \mathrm{C}$. Finally, the effect of concentration on the density of contaminated seawater can increase with decreasing concentrations of diesel oil, for example at $10 \mathrm{vol} \%$ the density is about $1000 \mathrm{~kg} / \mathrm{m}^{3}$ and it drops to $960 \mathrm{~kg} / \mathrm{m}^{3}$ at $50 \mathrm{vol} \%$ at $25^{\circ} \mathrm{C}$.

We recommend repeating the study for different crude oil components, taking into consideration other parameters such as wind speed and lower temperature around $4^{\circ} \mathrm{C}$ and below zero in case of accidents happening in cold regions. Longer time is also recommended, as the properties will be changed for long periods after oil spill accidents.

\section{Acknowledgements}

The authors gratefully acknowledge the School of Engineering at the Australian College of Kuwait for use of labs and facilities for testing.

\section{Conflict of Interest}

The authors declare no conflict of interest.

\section{References}

1. LECKLIN T., RYOMA R., KUIKKA S. A Bayesian network for analyzing biological acute and long-term impacts of an oil spill in the Gulf of Finland. Marine Pollution Bulletin. 62, 2235, 2011.

2. BANI-HANI E., EL HAJ ASSAD M. Recent Technologies in Mitigating Oil Spill Accidents. Petroleum and Petrochemical Engineering Journal. 4, 15, 2017.

3. ONWURAH I., OGUGUA V., ONYIKE N., OCHONOGOR A., OTITOJU O. Crude Oils Spills in the Environment, Effects and Some Innovative Clean-Up Biotechnologies. Int. J. Environ. Res. 4, 0720, 2007.

4. IVSHINA I., KUYUKINA M., KIRVOURUCHKO A., ELKIN A., MAKAROV S., CUNNINGHAM C., PESHKUR T., ATLAS R., PHILP J. Oil spill problems and sustainable response strategies through new technologies. Environmental Science: Processes and Impacts. 17, 0119, 2015.

5. JOHANSSON A., ERIKSSON L., HASSELLOV I., LANDQUIST H., BERG A., CARVAJAL G. Remote sensing for risk analysis of oil spills in the Arctic Ocean., Proceedings of the ESA Living Planet Symposium; 913, Great Britain, 2013.

6. GOERLANDT F. A model for oil spill scenarios from tanker collision accidents in the Northern Baltic Sea, Zeszyty Naukowe Akademii Morskiej w Szczecinie. 50 (122), 920, 2017.

7. LAFFON B., PASARO E., VALDIGLESIAS V. Effects of exposure to oil spills on human health: Updated review. Journal of Toxicology and Environmental Health. 19 (3), $0528,2016$. 
8. KESHAWY M., ABDUL-RAHEIM A., KABEL K., EL-KAFRAWY K., ABD EL-MOGHNY T. Synthesis, characterization and evaluation of polymeric oil sorbent for remediation of hydrocarbons spillage. Journal of Dispersion Science and Technology. 38 (5), 2936, 2017.

9. YANG M., KHAN F., GARANIYA V., CHAI S. Multimedia fate modeling of oil spills in ice-infested waters: an exploration of the feasibility of the fugacitybased approach. Process. Safety and Environmental Protection. 93, 0617, 2015.

10. ETKIN D. Estimating Cleanup Costs for Oil Spills. International Oil Spill Conference Proceedings. 1, 3539, 1999.

11. VANLOOCKE R., DE BORGER R., VOETS J., VERSTRAETE W. Soil and groundwater contamination by oil spills; problems and remedies. International Journal of Environmental Studies. 8, 99111, 1975.

12. ORDINIOHA B., BRISIBE S. The human health implications of crude oil spills in the Niger delta, Nigeria: An interpretation of published studies. Nigerian Medical Journal. 54 (1), 1016, 2013.

13. BUSKEY E., WHITE H., ESBAUGH A. Impact of oil spills on marine life in the Gulf of Mexico. Oceanography. 29 (3), 7481, 2016.

14. FROMETA J., DELORENZO M., PISARSKI E., ETNOYER P. Toxicity of oil and dispersant on the deep water gorgonian octocoral Swiftia exserta, with implications for the effects of the Deepwater Horizon oil spill. Marine Pollution Bulletin. 122, 9199, 2017.

15. BELLWOOD D., HUGHES T., FOLKE C., NYSTROM M. Confronting the coral reef crisis. Nature. 429, $2733,2004$.

16. JUSTIN R., SOKOVIC M. Industrialisation of Easy Boom. Archives of Materials Science and Engineering. 47 (2), 1016, 2011.
17. Cemaltoz A., Koseoglu B., SAKAR C. Marine environment protection: new technologies on oil spill response industry., First international congress on ship and marine technology; 19, Turkey, 2016.

18. BANI-HANI E., HAMMAD M., MATAR A., SADAGAT A., KHANAFER K. Numerical analysis of the incineration of polychlorinated biphenyl wastes in rotary kilns. Journal of Environmental Chemical Engineering. 4, 2432, 2016.

19. BANI-HANI E., HAMMAD M., MATAR A., SEDAGHAT A., KHANAFER K. Analysis of Polychlorinated Biphenyl Wastes Incineration in Rotary Kilns Model Development and Validation. International Journal of Mechanical Systems Engineering. 1, 0313, 2015.

20. BANI-HANI E., EL HAJ ASSAD M. Halogenated Wastes Safe Disposal: Polychlorinated biphenyls, International Journal of Petro chemistry and Research. 1, 7678, 2017.

21. BANI-HANI E., ALKHATEEB F., KHANAFER K. Analysis of variants within different models of diesel oil volatilization process using various soil materials. Special Topics and Reviews in Porous Media. 6, 6166, 2015.

22. AFENYO M., VEITCH B., KHAN F. A state-of-the-art review of fate and transport of oil spills in open and icecovered water. Ocean Engineering. 119, 3348, 2016.

23. FINGAS M., FIELDHOUSE B. Studies of the formation process of water-in-oil emulsions. Marine Pollution Bulletin. 47, 69 96, 2003.

24. World Health Organization. Desalination guidelines development for drinking water: Background., Guidelines; 11.03, Switzerland, 2004.

25. Infineum International Limited. Worldwide Winter Diesel Fuel Quality Survey 2016, https://www.fuelsinstitute.org/ fuelqualitycouncil/ResearchArticles/Worldwide-WinterDiesel-Fuel-Quality-Survey.pdf, accessed November, 2017. 